\title{
Betydningen af professionernes værdiskabelse for forskning og
}

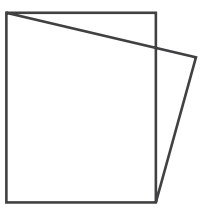

Tobias Høygaard Lindeberg, ph.d., chef for forskning og udvikling,

Professionshøjskolen Metropol
Formålet med denne artikel er at styrke betydningen af forskning og udvikling på professionshøjskolerne for professionernes virke ved at tilbyde modeller for professionel værdiskabelse. Professionshøjskolernes nuværende lovgrundlag fra 2013 har en stærk betoning af, at forskning og udvikling skal bidrage til professionernes værdiskabelse. Der tilbydes tre distinkte modeller for professionel værdiskabelse som afsæt for kvalificering af forskningsog udviklingsindsatsen: En model af professionel værdiskabelse som system, en produktionsfaktormodel og en evidensbaseret praksis som model for værdiskabelse

\section{Indledning}

Siden professionshøjskolerne i 2013 fik til at opgave at gennemføre forskning og udvikling til at understøtte uddannelser, er der opnået væsentlige resultater
(Danske Professionshøjskoler, 2017). Samtidig er der fortsat et behov for at tydeliggøre profilen for forskning og udvikling. Danmarks Evalueringsinstitut (2017: 9) påpeger, at forsknings- og udviklingsbegrebet er uklart, og at det kunne være en fordel med en tydeliggørelse fra et politisk niveau. Udgangspunktet for denne artikel er, at der også på professionshøjskolerne er brug for at udfolde forståelsen af, hvad forskning og udvikling betyder. Dermed afspejler artiklens erkendelsesinteresse forfatterens position som ansvarlig for forskning og udvikling på en professionshøjskole. Formålet med artiklen er at bidrage til den konceptuelle rammesætning af professionshøjskolernes forskning og udvikling med afsæt i den opgave, der er givet i lovgivningen, for på denne måde at kunne kvalificere grundlaget for konkrete forskningsindsatser. ${ }^{1}$ Kritik af de aktuelle rammer for 


\section{2013 markerede tre juridiske ændringer et omkalfatrende skift i grundlaget for arbejdet med viden.}

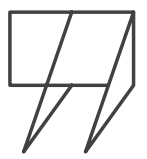

forskning og udvikling på professionshøjskolerne eller analyse af forskning og udvikling, som det udfolder sig på professionshøjskolerne i dag, falder således uden for denne artikels fokus.

Artiklen indledes med en beskrivelse af den forsknings-og udviklingsopgave, der er formuleret i lovgrundlaget for professionshøjskolernes i kraft af de ændringer, der blev gennemført i 2013. Lovgrundlaget er ikke alene centralt, fordi det forpligtiger institutionerne formelt, men også fordi det er et signal om, hvilke politiske forventninger der er til professionshøjskolerne, hvis bevillingen til forskning og udvikling skal fastholdes. I forhold til at formulere strategiske rammer for forskning og udvikling er lovgivningen imidlertid utilstrækkelig, og derfor inddrages i det følgende afsnit en forskningsmæssig forståelse af professioner og deres arbejde. Det afsnit fremlægger derfor tre forskelligartede bud på, hvordan der kan tænkes om professionel værdiskabelse. Det sidste afsnit rummer en diskussion af de tre modeller og af implikationerne for forskning og udvikling samt videre perspektiver.

Før og efter år 2013: Nyt lovgrundlag for professionshøjskolernes forskning og udvikling

Ved professionshøjskolernes etablering bestod forpligtelsen til at arbejde med videnudvikling i at "udføre udviklingsarbejde og varetage videncenterfunktioner" (Lov om professionshøjskoler for videregående uddannelser, 2007: §5). Der er rige muligheder for at diskutere og fortolke begreberne forskning og udvikling. Men det er dog begreber, der har officielle og internationalt anerkendte definitioner og en betydelig litteratur om begrebernes betydning.
Det samme er ikke tilfældet med "udviklingsarbejde" og "videncenterfunktion". I 2013 markerede tre juridiske ændringer et omkalfatrende skift i grundlaget for arbejdet med viden. For det første fik institutionerne med finansloven for 2013 midler til at arbejde med udviklings- og evidensbasering af professionshøjskolernes uddannelser. For det andet kom der en samlet stillingsstruktur for professionshøjskolerne, som gjorde forsknings- og udviklingsopgaven til en mulighed for alle undervisere, et krav til adjunktforløb og gav mulighed for at ansætte forskningsfaglige (og forskningsbedømte) ledere i form af docenter. Endelig blev der i 2013 vedtaget et forslag om ændring af lov om professionshøjskoler, som fra og med 1. januar 2014 gjorde det til en pligt for professionshøjskolerne at udføre anvendt forskning og udvikling (se Nielson 2017 for betydningen af disse 


\section{Samlet set tydeliggør lovgrundlaget, at forskning og udvikling på professions- højskolerne i sidste ende skal bidrage til at kvalificere professionernes opgavevaretagelse på arbejdsmarkedet.}

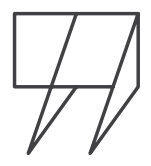

ændringer for forskning og udvikling på læreruddannelsen). Som det vil blive vist nedenfor, betoner alle dele af lovgrundlaget, hvad der samlet set kan betegnes som en stærk praksisorientering.

De midler, professionshøjskolerne modtager på finansloven, skal anvendes inden for rammerne af FrascatimanuaIen (Sørensen, 2012). Frascatimanualen (OECD, 2015) er OECD's manual for indsamling af statistik om forskning og udvikling. Manualen dækker grundforskning og anvendt forskning og udvikling, uanset om det er udført i erhvervslivet, på universiteter, universitetshospitaler eller andre steder. Manualen siger meget lidt om karakteren af den forskning og udvikling, der skal gennemføres. Finansloven stiller mere præcise krav om anvendelse af midlerne. For det første skal midlerne anvendes til praksisnær og anvendelsesorienteret forskning og udvikling. For det andet skal midlerne styrke "udviklings- og evidensbasering af uddannelserne" og give mulighed for "udvikling af uddannelsernes kvalitet og faglige niveau" (Finansministeriet, 2017: §19.27.08). ${ }^{2}$ Vel at mærke uddannelser, der først og fremmest skal imødekomme "behovet for kvalificeret arbejdskraft" (Lov om erhvervsakademiuddannelser og professionsbacheloruddannelser §1 stk. 2), og kvalificeres til "at varetage praksisnære, komplekse og udviklingsorienterede erhvervsfunktioner" (ibid. §3 stk. 2). Endelig præciseres det i finansloven, at forskning og udvikling skal gennemføres i samarbejde med universiteterne og det omgivende samfund.

I sommeren 2013 blev den samlede stillingsstruktur for professionshøjskolerne fastlagt. En af nyskabelserne var en stilling som docent, der bl.a. andet skal varetage faglig ledelse af forskning og udvikling, og kvalifikationskravene til denne stilling udgør også en central retningsangivelse for forskning og udvikling. En docent skal udover formel forskningskvalificering (ph.d.-grad eller tilsvarende) kunne dokumentere at være kvalificeret til bl.a. "selvstændigt og innovativt at udvikle ny viden inden for erhvervet eller professionen og bringe ny viden i spil i forhold til udviklingen af erhvervet eller professionen" (Styrelsen for Videregående Uddannelser, 2015). Ansættelseskriterierne prioriterer således praksisorientering over eksempelvis omfang og kvalitet af forskningsproduktion, som ikke er nævnt eksplicit. Med ændringen af professionshøjskoleloven bestemmes det, at professionshøjskolerne skal "varetage praksisnære og anvendelsesorienterede forsknings- og udviklingsaktiviteter og herigennem aktivt medvirke til, at ny viden tilvejebringes og bringes $i$ anvendelse i såvel den private som den offentlige sektor" (Lov om professionshøjskoler for videregående uddannelser, 2014: §3). Det bestemmes videre, at forsknings- og udviklingsaktiviteter skal 
Betydningen af professionernes værdiskabelse for forskning og udvikling

foregå "i tæt samspil med det aftagende arbejdsmarked, øvrige uddannelses- og videninstitutioner og det omgivende samfund" (ibid. §5), og at aktiviteterne "har til formål at tilvejebringe ny viden og konkrete løsninger på udfordringer inden for de erhverv og professioner, som professionshøjskolens uddannelser er rettet mod" (ibid. §5 stk. 2). ${ }^{3}$ Professionshøjskolelovens prioritering af praksisorientering kan ses i lyset af, at lovgrundlaget for både universiteter og sektorforskningsinstitutioner dels præciserer, at de skal forske "indtil højeste internationale niveau" (Lov om universiteter §2 og Lov om sektorforskningsinstitutioner §2), dels at loven, i modsætning til lovgrundlaget for de to andre institutionstyper, ikke giver hjemmel til grundforskning. ${ }^{4}$ Forskningsmæssig excellence er ikke et selvstændigt formål, hvilket dog ikke betyder, at kvaliteten af den gennemførte forskning er ligegyldig. Samlet set tydeliggør lovgrundlaget, at forskning og udvikling på professionshøjskolerne i sidste ende skal bidrage til at kvalificere professionernes opgavevaretagelse på arbejdsmarkedet - først og fremmest ved at bidrage til bedre uddannelser. Fokus i denne artikel er på karakteren af forskning og udvikling og derfor behandles det centrale spørgsmål om koblingen mellem forskning og uddannelse ikke.

\section{Forståelse af professioner og deres arbejde}

Professioner og deres opgaver er behandlet indgående i forskningslitteraturen. Talcott Parsons (1939) var en tidlig bidragyder til denne diskussion, idet han erstattede forståelsen af professioner som uegennyttige med en forståelse af professionerne som en særlig type institutionel struktur, der løser særlige sociale funktioner. Forestillingen om professioner som bærer af en særlig samfundsmæssig funktion er siden blev problematiseret bl.a. fra et magtperspektiv (Harrits, 2011), og der er sået tvivl om, hvorvidt det er meningsfuldt at skelne entydigt mellem professioner og andre erhverv (Evetts, 2012). I forhold til ambitionen om at kvalificere rammesætningen af professionshøjskolernes forskning og udvikling er det tilstrækkeligt - på et overordnet niveau - at indkredse forståelsen af professioner og deres opgaver. Der forekommer at være i hvert fald to elementer, som centrale forskere er enige om. ${ }^{5}$ Det første er, at professioner fungerer som del af et arbejdsmarked; det andet er, at de er baseret på en videnmæssig specialisering, som ikke kan standardiseres.

Professioner agerer på et arbejdsmarked, hvor de, som alle andre erhverv, er afhængige af at kunne skabe en indtægt (Freidson, 2001), og hvor de arbejder med problemer, der kan gøres til genstand for ekspertservice (Abbott, 1988: 35). De er med andre ord afhængige af at skabe en ydelse, som deres arbejdsgiver eller deres klienter opfatter som værdifuld. For langt de fleste af de professioner, professionshøjskolerne uddanner til, betyder det, at professionerne skal kunne levere ydelser, der indfrier de formål, der er beskrevet i den lovgivning, der hjemler deres ansættelse (for eksempel folkeskoleloven eller serviceloven), samt de forventninger der er til professionernes ydelser i politisk besluttede strategier og planer på ministerielt, regionalt eller kommunalt niveau. ${ }^{6}$ Det kan synes selvindlysende, at professionerne skal skabe værdi i en markedsmæssig betydning, men det er implikationerne for, hvad det er mest relevant at forske i ikke altid. Hvis ikke det kan forventes, at forskning og udvikling giver resultater, som efterspørges på det marked, professionernes agerer på, kan det ikke forventes, at forskningen og udviklingen får markant gennemslag på professionernes praksis. Forskning og udvikling, der skal bidrage til at kvalificere professionernes opgavevaretagelse på arbejdsmarkedet, må have som udgangspunkt at styrke professionernes værdiskabelse i den forstand, at fokus er på at styrke kapaciteten til at løse problemer og indfri potentialer hos de brugergrupper, de arbejder med. Det betyder, at forskning inden for eksempelvis professionernes identitet, oplevelser, historie og kultur ikke i sig selv kan udgøre en primær forskningsgenstand i denne sammenhæng. På denne baggrund bliver det vigtig for tilrettelæggelsen af professionshøjskolernes forskning og udvikling at kunne træffe kvalificerede beslutninger om, hvilke konkrete forskningsopgaver der vil kunne styrke professionernes værdiskabelse. Et aspekt af dette arbejde er at beslutte, hvilke samfundsmæssige udfordringer og muligheder professionerne kan forventes at skulle adressere og skabe værdi i forhold til. På dette punkt er der god hjælp at hente i det store forskningspolitiske fokus på samfundsmæssige udfordringer og muligheder for forskning. Senest tilbyder FORSK2025 et konkret prioriteringsgrundlag og - mere generelt - en ramme for at reflektere over, hvilke typer af samfundsudfordringer der er relevante at forske i (Styrelsen for Forskning og uddannelse, 2017). 
Tema: Professionshøjskoler i 10 år

I forhold til at beskrive, hvordan professionerne skaber værdi ved at bidrage til at løse disse udfordringer, er der til gengæld ikke generelle modeller eller tilsvarende tilgængelige. Som det vil fremgå af næste afsnit, behandles problemet på et generelt niveau i professionslitteraturen.

Det andet gennemgående træk ved beskrivelsen af professioner er, at anvendelse af viden spiller en afgørende rolle i professionelle ydelser (se Smeby og Terum, 2011). Abbott (1988: 8) definerer ligefrem professioner som erhverv, der anvender en abstrakt viden på specifikke tilfælde. Freidson (2001) betoner, at professionelt arbejde er så specialiseret, at det forudsætter særlig viden samtidig med, at det ikke lader sig standardisere, således at ukvalificerede kan løse opgaven. Desværre kommer Freidson (2001) ikke med et konkret bud på, hvordan professionelt arbejde skaber værdi, idet han fokuserer på, hvordan det professionelle arbejde organiseres. Abbott kommer (som det vil fremgå nedenfor) med, hvad der kan opfattes som elementer i en model, men er primært interesseret $i$ at udbygge en forståelse for relationerne mellem professioners jurisdiktioner. Det betyder, at der er behov for at bidrage til en forståelse af de mekanismer, professionernes værdiskabelse sker igennem, som led i kvalificeringen af den konceptuelle rammesætning af professionshøjskolernes forsknings- og udviklingsarbejde. Det er her vigtigt at understrege, at der ikke ligger en forestilling om en simpel, eller for dens sags skyld kompliceret, kausalitet (Rogers, 2008) mellem videnudvikling og værdiskabelse til grund for dette synspunkt. Kausaliteten er som regel yderst kompleks i professioners arbejde, men det ændrer ikke ved vigtigheden af, at bestemte professionelle handlinger forventeligt har bestemte effekter for bestemte grupper.

\section{Tre billeder af professionel værdiskabelse}

Professionshøjskolerne uddanner en lang række af professionelle, der har vidt forskellige arbejdsfelter. De fleste bioanalytikere deltager i en arbejdsproces, hvor højteknologi spiller en konstituerende rolle. For de fleste pædagoger er højteknologi et hjælpemiddel, der bruges som understøttelse af en kerneydelse, der udøves relationelt. Nogle professioner indgår i et dagligt arbejdsfællesskab med andre professioner, mens andre vil have arbejdsdage, hvor de alene ser kollegaer inden for egen profession. Forskellige professioner skaber utvivlsom værdi på forskellige måder. Ambitionen med at beskrive modeller for professionel værdiskabelse er at kvalificere drøftelsen af værdiskabelse i de enkelte professioner - ikke at finde den mest retvisende model med et standardiseringsformål for øje. Derfor er der taget udgangspunkt i tre modeller, der rummer distinkte bud på, hvordan professionelle skaber værdi, der i drøftelser af konkrete professioner kan kombineres eller bruges som afsæt for at formulere helt andre bud.

\section{Professionelt arbejde som system} Abbott (1988) har i bogen The Systems of Professions udfoldet en analyse af professionernes rolle i det moderne samfund og beskrevet, hvordan de opstår, udvikler sig og kæmper om legitimitet og arbejdsdeling. Abbott forstår professioner som vidensystemer og konkretiserer professionelt arbejde i tre dele. En del er at indsamle viden om en borgers problem for at klassificere det, herunder afgøre, om det er et problem, der falder inden for professionens arbejdsområde. I klassificeringen af problemer kombineres oplysninger om det specifikke tilfælde med det professionelle vidensystem, fx gennem tests og prøver. Herved udskilles problemet som værende professionelt relevant bl.a. ved at bortsortere øvrig personlig kompleksitet.

En anden del af det professionelle arbejde er at foreskrive mulige løsningshandlinger for den identificerede problemstilling. Altså at oversætte viden fra det professionelle vidensystem til handlemuligheder i det konkrete tilfælde, der forventes at føre til bestemte resultater. Selvom Abbott (1988: 40) bruger diagnose og behandling som metafor for disse to processer i sin analyse af tre cases uden for sundhedsvæsnet (bibliotekarer, jurister og psykologer), så har begreberne så stærke medicinske konnotationer, at det vil være en fordel at bruge andre begreber, hvis modellen skal kunne bruges til bredere diskussion. Nedenfor bruges i stedet problembestemmelse og løsningshandlinger. Problemet skal forstås som en professionel problemstilling - for borgeren kan det opleves som en mulighed. Eksempelvis er rehabilitering af en raskmeldt et professionelt problem for ergoterapeuten, men en mulighed for borgeren.

Den tredje og sidste del af Abbotts konkretisering af det professionelle arbejde, kalder han for "inference", der kan oversættes til at drage en slutning eller at ræsonnere. Det er den proces, der kobler et specifikt problem med 


\section{Jo tydeligere det er, at videnbasen ikke kan håndteres ved at følge en manual, jo stærkere en profession.}

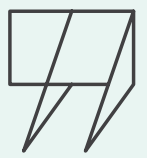

en specifik løsning. Begrebet dækker over det at nå frem til én behandling (eller en kombination af flere) ud fra den diagnose, klienten har fået (Abbott, 1988: 48).

De tre dele udgør ikke en fast sekvens. De kan foregå parallelt og i nogle tilfælde i omvendt rækkefølge (illustreret i modellen ved de dobbeltrettede pile). Dette er en vigtig pointe, ikke mindst $i$ forhold til de professioner, der arbejder med større grupper. En lærer er nødt til at undervise fra første dag med en ny klasse ud fra en generel forventning til det faglige udgangspunkt på det pågældende klassetrin, og det vil bl.a. være gennem undervisningen, der opnås viden, der kvalificerer problembestemmelse, som så gennem professionelt ræsonnement giver anledning til at ændre undervisningen (løsningshandlinger).

Figur 1: Professionel vœrdiskabelse som system

Problembestemmelse $\rightarrow \leftarrow$ Ræsonnement $\rightarrow \leftarrow$ Løsningshandlinger

Note: Egen tilvirkning
Abbott analyserer, hvordan professioner tilkæmper sig og fastholder monopol på løsning af specifikke problemer i samfundet. For at kunne opnå et sådant monopol er to forhold afgørende: For det første skal der være en abstrakt videnbase, der gør det muligt at identificere og klassificere problemer med høj pålidelighed og relevans for det professionelle arbejde. Der skal ydermere være velbeskrevne forskrifter for effektive løsningshandlinger. For det andet skal medlemmerne af professionen være i stand til at udøve et professionelt skøn, der kobler de rette konkrete problemer med de rette konkrete løsningshandlinger. Det kan skyldes, at indikationerne på problembestemmelse ofte er flertydige, fordi der som regel er flere mulige løsningshandlinger, der kan prøves, eller fordi det er nødvendigt løbende at ræsonnere over diagnosen i takt med, at behandlingen udfolder sig. Jo mere veldokumenteret virkningerne af professionens evne til at løse problemer er, jo stærkere er professionen på arbejdsmarkedet. Jo tydeligere det er, at videnbasen ikke kan håndteres ved at følge en manual, jo stærkere en profession. Hvis der ikke er brug for professionel dømmekraft i ræsonnementet, er der intet grundlag for legitimt at hævde, at kun medlemmer af professionen har adgang. Netop fordi ræsonnement kræver udøvelse af skøn gennem professionel dømmekraft, bliver det afgørende, at det udøves af personer med særlige uddannelser (Abbot, 1998: 195). Den professionelle værdiskabelse stiger således i takt med, at videnbasen bliver mere robust og $i$ takt med, at behovet for udøvelse af skøn er tilsvarende stort.

\section{En produktionsfaktormodel for professionelt arbejde}

I 1990 mødtes en gruppe eksperter i Utstein Kloster i Norge. Det blev det første af en række møder, som resulterede i Utstein-guidelines for hjertestop. Et element i disse guidelines er en formel for overlevelse. Formelen beskriver de 


\section{Forsknings- og udviklingsindsatser bør kunne forklares og forsvares med afsæt i, hvordan professionerne skaber værdi i forhold til de samfundsmæssige udfordringer og muligheder, professionen må forventes at skulle adressere.}

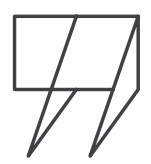

faktorer, der er afgørende for at overleve et hjerteanfald. Formlen ser ud som følger (Søreide et al., 2013):

Medical science $x$ Educational efficiency $x$ Local implementation $=$ survival $^{7}$

Medical science betyder i denne sammenhæng kvaliteten af forskrifter for, hvad der bør gøres i tilfælde af hjerteanfald. Educational efficiency omhandler, hvor effektivt medicinsk viden omsætter sig i kompetencer, der gør personale i stand til at gennemføre hjerteredning. Endelig handler implementering om at lede, oversætte, engagere og skabe information om målopfyldelse på måder, der giver mulighed for succesfuld hjerteredning (ibid.).

Hjerteredning er en meget afgrænset problemstilling sammenlignet med rigtig mange andre problemstillinger, som professionelle håndterer. Men af tre grunde er modellen alligevel værd at løfte op på et generelt niveau. For det første skaber den en sammenhæng mellem de faktorer, der er med til at skabe værdi for borgeren. For det andet sætter den på formel, at hverken fremragende viden, uddannelse eller lokal organisering, er tilstrækkeligt til at skabe fremragende professionelt arbejde. $\mathrm{Er}$ der en af faktorerne, der scorer meget lavt, vil effekten for borgerne være ubetydelig - uanset hvor fremragende de andre faktorer præsterer. For det tredje giver den anledning til at udfordre om det er mere viden (altså forskning og udvikling), der er behov for. En generalisering af modellen kan se således ud:

Redskabsgjort viden $\mathrm{x}$ kompetencer $\mathrm{x}$ organisering $=$ effekt for borgeren

Redskabsgjort viden kan i denne sam- menhæng forstås som viden om hvilke typer af professionelle indsatser, der har hvilke effekter for bestemte grupper af borgere. Viden kan have karakter af metoder, programmer eller være indlejret i teknologi. Det afgørende er, at det er viden, der fremskriver bestemte typer af professionelle handlinger. Kompetencer kan forstås som den professionelle formåen til at omsætte redskabsviden i handlinger, herunder og ikke mindst evnen til at aktivere viden på relevante måder i konkrete relationer over for konkrete borgere. Endelig kan organisering forstås som de fysiske, formelle, kulturelle og ledelsesmæssige rammer, de professionelle handlinger udfolder sig inden for. På denne måde kan modellen opfattes som en oversigt over de centrale produktionsfaktorer i professionelt arbejde.

Hvor modellen for professionelt arbejde 
Betydningen af professionernes værdiskabelse for forskning og udvikling

som system sondrer tydeligt mellem forskellige dele af det professionelle arbejde, er fokus her i stedet på, hvad der skaber det. Redskabsgjort viden vil være relevant for at identificere problembestemmelse såvel som løsningshandlinger, mens kompetence vil gå igennem alle tre dele af modellen for professionelt arbejde som system. ${ }^{8}$

\section{Professionel værdiskabelse som evidensbaseret praksis}

Som led i den ophedede debat om definitionen på evidensbaseret medicin, skrev David Sackett m.fl. (1996) en leder i BMJ (tidl. British Medical Journal), der siden er blevet referencepunkt for evidensbaseret praksis generelt og ikke blot inden for medicin. I lederen anlægges der en pragmatisk tolkning af evidensbaseret medicin, der hverken er en instrumentalisering af medicinsk praksis eller en fortsættelse af gængs praksis. Den centrale pointe for Sackett er, at selv om der er betydeligt behov for systematisk brug af videnskabelig viden i medicinsk praksis, er evidensbaseret medicin ikke et spørgsmål om evidensens "tyranni" - evidensbaseret medicin er ikke "cookbook medicine" (ibid.). For Sackett er det afgørende, at evidensbaseret praksis er et spørgsmål om ikke kun at bruge individuel, klinisk ekspertise og den bedste tilgængelige viden, men også om at inddrage patienternes præferencer og værdier. Det springende punkt bliver en balancering af de tre videndomæner (klinisk erfaring og ekspertise, bedste tilgængelige viden og patientens synspunkter). På denne måde bliver det professionelle skøn placeret helt centralt i modellen. Siden er information fra praksiskonteksten i nogle sammenhænge blevet tilføjet som et fjerde videndomæne, der dækker over de organisatoriske erfaringer og viden, der er i en bestemt organisatorisk sammenhæng (Hoffman et al., 2010: 4).

På samme måde, som i beskrivelsen af professionel værdiskabelse som system, bliver professionel dømmekraft den helt afgørende faktor i denne model. Det er professionel dømmekraft, der integrerer de fire videndomæner. Modellen for evidensbaseret medicin er sammenlignelig med produktionsfaktormodellen med den tilføjelse, at modellen eksplicit inddrager borgerens situation, værdier og præferencer.

\section{Pejlemærker for forskning og udvikling} Formålet med artiklen har været at bidrage til den konceptuelle rammesætning af professionshøjskolernes forskning og udvikling med afsæt i den opgave der er givet i lovgivningens rammer for at kunne kvalificere grundlaget for konkrete forskningsindsatser. Kon-

Figur 2: Professionel vœrdiskabelse som evidensbaseret praksis

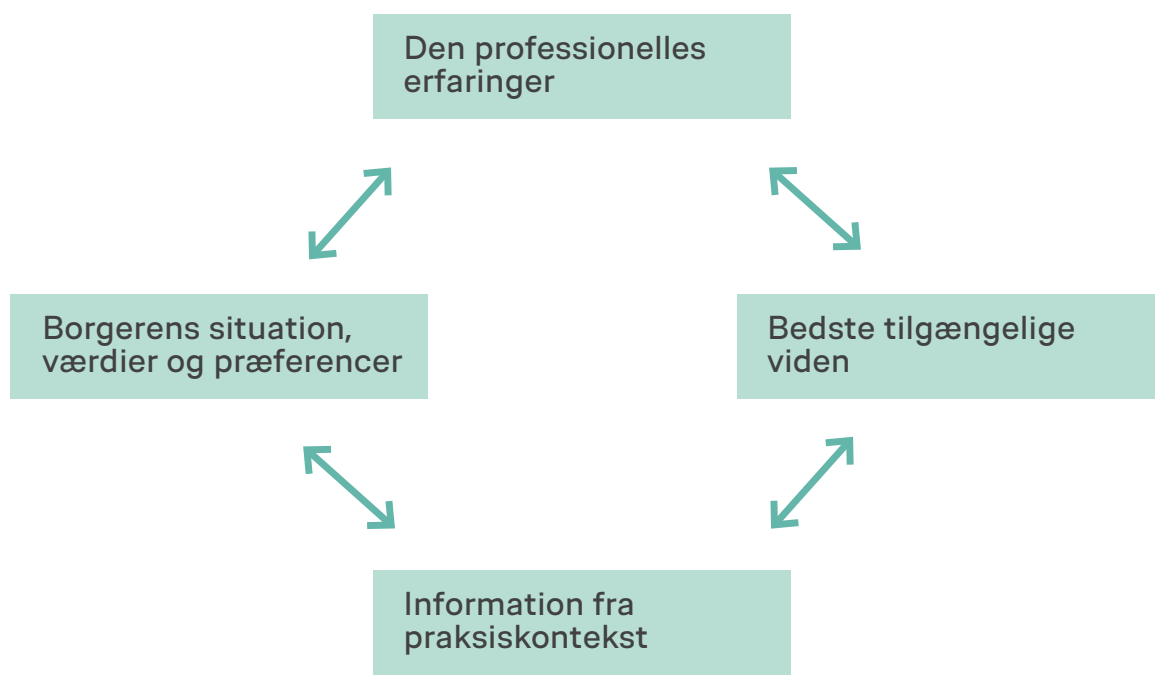

Note: Egen tilvirkning på baggrund af Hoffmann et al. (2010). kret har artiklen beskrevet tre modeller for, hvordan professioner skaber værdi på arbejdsmarkedet. I forhold til implikationer for beslutningen om konkrete forskningsindsatser kan følgende fire mere specifikke pejlemærker udledes af ovenstående analyse.

For det første bør der i lyset af det stærke fokus på en robust videnbase på tværs af de analyserede modeller være fokus på at udvikle og undersøge hvilke indsatser, der kan løse hvilke problemer og for hvilke typer af borgere. Når fokus er på, hvordan professionerne kommer til at skabe værdi for borgerne, bliver det afgørende at forpligte sig på at undersøge, om det faktisk sker. I udviklingen af indsatser kan det dreje sig om involvering af et borgerperspektiv i udviklingsfasen. Drejer det sig om pilotafprøvning kan det være undersøgelser af, hvorvidt det er plausibelt, at designet af indsatsen vil give de forventede effekter 
Tema: Professionshøjskoler i 10 år

for borgerne. Drejer det sig om relativt modne og afprøvede indsatser, kan det dreje sig om kontrafaktiske evalueringsdesigns af effekter for borger.

For det andet betyder det gennemgående fokus på kompetencer og professionelt skøn i analysen ovenfor, at der bør være fokus på, hvordan kompetencer, der er afgørende for professionel værdiskabelse, kan trænes. Det kan eksempelvis dreje sig om at undersøge, hvilken effekt det har for borgerne, hvis de professionelle bliver superviseret, hvis det vurderes, at samtalekompetencer er centrale for professionel værdiskabelse (se SCIE, udateret).

For det tredje giver såvel produktionsfaktormodellen som modellen for evidensbaseret praksis anledning til at overveje, hvilken betydning lokal implementering, ledelse og organisering har for værdiskabelsen hos borgerne.

Det er i denne sammenhæng centralt, at når forskning og udvikling på professionsuddannelserne først og fremmest skal give værdi gennem omsætning i uddannelse, vil det være afgørende, at denne type spørgsmål foregår $i$ tilknytning til uddannelser rettet mod ledere i professionerne, eller at der er fokus på forhold, som kan håndteres af medarbejderne selv, $\mathrm{fx}$ i relation til teamsamarbejde i skolen.

For det fjerde giver modellen for evidensbaseret praksis anledning til at overveje, om undersøgelser af borgerens situation, værdier og præferencer kan få betydning for den professionelle værdiskabelse hos borgeren. Det kan fx dreje sig om involvering af patienter i deres egen behandling og involvering af elever i tilrettelæggelsen af undervisningen.

\section{Perspektiver}

Ovenfor er der argumenteret for, at professionshøjskolernes forsknings- og udviklingsindsatser bør kunne forklares og forsvares med afsæt i, hvordan professionerne skaber værdi i forhold til de samfundsmæssige udfordringer og muligheder, professionen må forventes at skulle adressere. Det kræver, at forsknings- og udviklingsaktiviteterne er koblet til analyser af, hvilke samfundsudfordringer der er afgørende for professionerne, og til analyser af, hvordan professionerne skaber værdi. Det vil være velkomment med yderligere bidrag til disse spørgsmål, men der er også andre spørgsmål, som er centrale at drøfte i forhold til professionshøjskolernes forskning og udvikling.

For det første er der spørgsmålet om, hvilke forskelle og ligheder der er mellem profilerne for forskning og udvikling hos professionshøjskoler og andre videninstitutioner. Professionshøjskolerne har det tilfælles med universiteterne, at den væsentligste mekanisme til omsætning af viden er uddannelse. Men i forhold til spørgsmål om formålet med forskning og udvikling vil det måske være mere relevant at sammenstille professionshøjskolerne med institutter for Godkendt Teknologisk Service (for eksempel Teknologisk Institut), hvor forskning og udvikling har til formål at kvalificere videnservice til primært små og mellemstore virksomheder, eller med universitetshospitaler, hvor et centralt formål er bedre behandling af patienterne.

Et andet centralt spørgsmål er, hvad det betyder i praksis, at forskerne på professionshøjskolerne, i modsætning til forskerne på universiteterne, ikke har lovhjemlet forskningsfrihed. På den ene side må det betyde, at de konkrete forsknings- og udviklingsaktiviteter i sidste ende besluttes af ledelsen. På den anden side er det oplagt, at institutionens formelle ledelse ikke kan beslutte resultatet af en analyse. Mellem disse yderpunkter er der en række andre forhold, hvor det er mindre oplagt, hvor grænsen går for ledelsens beslutningskompetence. 
Betydningen af professionernes værdiskabelse for forskning og udvikling

\section{REFERENCES}

Abbott, A. (1988): The System of Professions: An Essay on the Division of Expert Labor, Chicago: University of Chicago Press.

Danske Professionshøjskoler (2017). Profviden:

Professionshøjskolernes videnregnskab for forskning og udvikling 2016, København: Danske Professionshøjskoler.

EVA (2017). Forskning og udvikling på professionshøjskolerne som vej til uddannelseskvalitet. København: Danmarks Evalueringsinstitut.

Evetts, J. (2012). Professionalism: Value and ideology. Sociopedia. isa 61, 778-796. https://doi.org/10.1177/0011392113479316.

Finansministeriet (2017). Forslag til finanslov for finansåret 2018, København: Finansministeriet.

Harrits, G.S. (2011). Professionsfeltet: sociale relationer og sociale kampe. I M.B. Johansen \& S.G. Olesen (red.) Professionernes sociologi og vidensgrundlag. Århus: VIA Systime.

Hoffmann, T., Bennett, S. \& del Mar, D. (2010). Evidence-based practice across the health professions, Chatswood: Elsevier Australia.

Lov om erhvervsakademiuddannelser og professionsbacheloruddannelser nr. 986 af 18 august 2017.

Lov om professionshøjskoler for videregående uddannelser nr. 562 af 6. juni 2007.

Lov om professionshøjskoler for videregående uddannelser nr. 936 af 25. august 2014.

Lov om sektorforskningsinstitutioner nr. 581 af 1. juni 2014.

Lov om universiteter nr. 261 af 18 marts 2015.

Nielson, Bo (forthcoming). Anvendelsesforpligtet grundforskning på læreruddannelsen. Studier i lœreruddannelsen og -profession.

OECD (2015). Frascati Manual: Guidelines for Collecting and Reporting data on Research and Experimental Development. Paris: OECD.

Parsons, T. (1939): The professions and social structure. Social Forces, 17, 457-467.
Rogers, P. (2008). Using programme theory for complex and complicated programs. Evaluation, 14, 29-48. DOI: $10.1177 / 1356389007084674$.

Sackett, D.L., Rosenberg, W.M., Gray, J.A., Haynes, R.B. \& Richardson W.S. (1996). Evidence based medicine: what it is and what it isn't. BMJ, 312, 71-2. DOI: 10.1136/bmj.313.7050.170c

SCIE (udateret). Review of litterature on the use of video and associated technology to support supervision \& re rective practice. London: The Social Care Institute for Excellence. ttps://www.phmetropol.dk/ /media/dokumenter/forskning/ institut+for+socialt+arbejde/review2dk.pdf?la=da.

Smeby, J.C. \& Terum, L.I. (2011). Akademisering av profesjonshøyskolene. I M.B. Johansen \& S.G. Olesen (red.) Professionernes sociologi og vidensgrundlag. Århus: VIA Systime.

Stokes, D. E. (1997). Pasteur's Quadrant: Basic Science and Technological Innovation. Brookings Institution Press.

Søreide, E., Morrisonc, L., Hillmane, K., Monsieurs, K., Sundei, K., Zidemanj, D., Eisenbergl, M., Sterz, F., Nadkarni, V.N., Soar, J., \& Nolanp, J.P. (2013). The formula for survival in resuscitation, Resuscitation, 84, 1487-1493. DOI: 10.1016/j. resuscitation.2013.07.020

Sørensen, P.M. (2012). Udmelding af forventet fordeling af pulje til forskningstilknytning samt udviklings- og evidensbasering, brev til professionshøjskoler og Danmarks Medie- og Journalisthøjskole 12. oktober 2012. Købehavn: Styrelsen for Videregående Uddannelse og Uddannelsesstøtte.

Styrelsen for Forskning og uddannelse (2017). FORSK2025: Fremtidens løfterige forskningsområder. København: Styrelsen for Forskning og uddannelse.

Styrelsen for Videregående Uddannelse (2016). Bekendtgørelse om stillingsstruktur for undervisere ved erhvervsakademier, professionshøjskoler og Danmarks Medie- og Journalisthøjskole nr. 1065 af 4. juli 2016. 
Tema: Professionshøjskoler i 10 år

Styrelsen for Videregående Uddannelser (2015). Bekendtgørelse om lektorkvalificering, lektorbedømmelse og docentbedømmelse af undervisere ved erhvervsakademier, professionshøjskoler, Danmarks Medie- og Journalisthøjskole og visse maritime uddannelsesinstitutioner nr. 990 af 28. august 2015.
TrygFonden (2015). Skal vi hjœlpe dig med at hjœlpe?, upubliceret.

\section{ENDNOTES}

1 Denne artikel anvender begreberne profession og professionel om alle dimittendgrupper fra professionshøjskolerne, velvidende at der er betydelig forskel i, hvilken grad de er konsoliderede som profession i såvel professionssociologisk som gængs forstand.

2 Formuleringerne har varieret gennem de forskellige finanslove.

3 Den nuværende professionshøjskolelov viderefører dog en uklarhed i begreberne ved i lovbemærkninger at anføre, at forsknings-og udviklingsaktiviteter på professionshøjskolerne ud over aktiviteter, der lever op til alment og internationalt anerkendte definitioner for forskning og udvikling, rummer "væsentlige aktiviteter som falder uden for disse definitioner". Disse aktiviteter defineres ikke nærmere, men der oplistes en række eksempler. Oplistningen indledes med bl.a. og afsluttes med m.v. I denne artikel bruges forskning og udvikling som defineret i Frascati-manualen.

4 Dog er Donald Stokes' (1997) kritik af distinktionen mellem grundforskning og anvendelsesorientering/udvikling relevant i denne sammenhæng.
5 Eliot Freidson (2011) og Andrew Abbott (1988) er to markante forskere inden for professioner. Mens Abbott analyserer i professionsudvikling og intern konkurrence, er Freidson bl.a. interesseret $i$ at formulere professioner som en tredje logik ved siden af marked og bureaukrati og viderefører på denne måde dele af ræsonnement fra Parsons' forståelse af professioner.

6 Vurderingen af, hvornår en ydelse har værdi, er kompleks. Jeg har behandlet dette spørgsmål i Lindeberg 2007. Det ændrer imidlertid ikke ved, at professionerne har et problem, hvis ikke dem, der betaler deres løn eller honorar, har en opfattelse af, at der leveres værdifulde ydelser i forhold til relevante problemer.

7 Jeg skylder referencen til Søriede et al. og idéen til at generalisere formlen til TrygFonden (2015).

8 I den meget korte gengivelse af professionelt arbejde som system kan det se ud, som om Abbott ikke inddrager organisering i sin analyse. Det er ikke tilfældet (Abbott, 1988: kapitel 5). 